\title{
ТОЛЕРАНТНА КОМПЕТЕНТНІСТЬ ПЕДАГОГА: КОНЦЕПЦІЯ Й ЕМПІРИЧНА ВЕРИФІКАЦІЯ
}

\section{Вірна Жанна}

Волинський національний університет імені Лесі Українки, м. Луцьк, Україна,

Virna.Zhanna@vnu.edu.ua

ORCID : https://orcid.org/0000-0001-8134-2691

\section{Гайдук Галина}

Волинський коледж Національного університету харчових технологій, м. Луцьк, Україна,

Galina.Gayduk123@gmail.com

ORCID : https://orcid.org/0000-0003-2920-2530

Mema. У статті здійснено теоретико-емпіричне обгрунтування толерантної компетентності педагога. Мета роботи - теоретичне обгрунтування та емпірична верифікація толерантності педагога засобом операціоналізації мотиваційносмислових індикаторів толерантної компетентності та механізмів іiї функціонування залежно від стажу його професійної діяльності.

Методи. Основними методами дослідження є теоретичні (аналіз, синтез, порівняння, абстрагування, узагальнення, систематизація), емпіричні (бесіда, спостереження, тестування), методи математичної статистики (дискримінантний аналіз, критерій Краскела-Уолеса, факторний аналіз, множинний регресійний аналіз).

Результати. У ході теоретичного узагальнення основних тенденцій i концепцій вивчення професійної толерантності запропоновано теоретичну модель структурної організації професійної толерантності педагога, у якій виокремлено когнітивно-інформативний, емоційно-регуляційний, особистіснокомунікативний та поведінково-нормативний компоненти й зазначено операційно-смисловий, рефлексивно-смисловий, мотиваційно-регуляційний та мотиваційно-контролюючий модуси їх продуктивного функціонування. Емпірично експліковано зміст прояву професійної толерантності засобом операціоналізації мотиваційно-смислових індикаторів толерантної компетентності в емоційнораціональній, автономно-безкорисливій, статусно-нормативній та інтелектуально-продуктивній формах i механізми їх функціонування (адаптаційноідентифікаційний, ідентифікаційно-моральний, морально-продуктивний, продуктивно-адаптаційний) залежно від стажу професійної діяльності педагогів.

Висновки. У висновках зазначено, що зосередження уваги на виокремлених механізмах функціонування толерантної компетентності педагога дасть змогу

ISSN 2308-3743 (Online), ISSN 2227-1376 (Print)

(C) Вірна Ж., Гайдук Г., 2020. Ця стаття відкритого доступу на умовах CC BY-NC 4.0 
визначити адекватний вплив мотиваційно-смислової детермінації на систему професійної саморегуляції фахівця.

Ключові слова: толерантність, професійна толерантність, мотиваційносмислові чинники, толерантна компетентність, педагог.

Virna Zhanna, Haiduk Halyna. Tolerant Competence of a Pedagogue: the Concept and Empirical Verification. Purpose. The article is devoted to the theoretical and empirical grounding of tolerant competence of a pedagogue. The aim of the presented material is theoretical grounding and empirical verification of pedagogue tolerance through operationalization of motivational and semantic indicators of tolerant competence and mechanisms of its functioning depending on professional activity experience.

Methods. The main methods are theoretical (analysis, synthesis, comparison, abstraction, generalization, systematization), empirical (conversation, observation, testing), and methods of mathematical statistics (discriminant analysis, Kruskal-Wallis test, factor analysis, multiple regression analysis).

Results. In the course of theoretical generalization of the main tendencies and concepts of professional tolerance studying, the theoretical model of structural organization of professional tolerance of a pedagogue has been suggested, in which cognitive and informative, emotional and regulatory, personality and communicative, behavioural and normative components have been singled out; operational and semantic, reflexive and semantic, motivational and regulatory, motivational and controlling modes of their productive functioning have been stated. The manifestation content of professional tolerance has been empirically explicated through operationalization of motivational and semantic indicators of tolerant competence in emotional and rational, autonomous and selfless, status and normative, intellectual and productive forms and mechanisms of their functioning (adaptational and identificational, identificational and moral, moral and productive, productive and adaptational), depending on professional activity experience of pedagogues.

Conclusions. The conclusions indicate that concentration on the singled out functioning mechanisms of tolerant competence of a pedagogue will allow determining the appropriate influence of motivational and semantic determination on a system of professional self-regulation of a specialist.

Key words: tolerance, professional tolerance, motivational and semantic factors, tolerant competence, pedagogue.

Вирна Жанна, Гайдук Галина. Толерантная компетентность педагога: концепция и эмпирическая верификация. Цель. В статье обосновывается теоретико-эмпирическая толерантная компетентность педагога. Цель исследования - теоретическое обоснование и эмпирическая верификация толерантности педагога средством операционализации мотивационно-смысловых индикаторов толерантной компетентности и механизмов ее функционирования в зависимости от стажа его профессиональной деятельности. 
Meтоды. Основными методами работы являются теоретические (анализ, синтез, сравнение, абстрагирование, обобщение, систематизация), эмпирические (беседа, наблюдение, тестирование) и методы математической статистики (дискриминантный анализ, критерий Краскела-Уоллеса, факторный анализ, множественный регрессионный анализ).

Pезультаты. По ходу теоретического обобщения основных тенденций и концепций изучения профессиональной толерантности, предлагается теоретическая модель структурной организации профессиональной толерантности педагога, в которой выделяются когнитивно-информативный, эмоциональнорегуляционный, личностно-коммуникативный и поведенчески-нормативный компоненты и указываются операционно-смысловой, рефлексивно-смысловой, мотивационно-регуляционный и мотивационно-контролирующий модусы их продуктивного функционирования. Эмпирически эксплицировано содержание проявления профессиональной толерантности средством операционализации мотивационно-смысловых индикаторов толерантной компетентности в эмоционально-рациональной, автономно-бескорыстной, статусно-нормативной и интеллектуально-продуктивной формах и механизмы их функционирования (адаптационно-идентификационный, идентификационно-нравственный, морально-продуктивный, продуктивно-адаптационный) в зависимости от стажа профессиональной деятельности педагогов.

Bыbоды. Отмечается, что сосредоточение внимания на выделенных механизмах функционирования толерантной компетентности педагога позволит определить адекватное влияние мотивационно-смысловой детерминации на систему профессиональной саморегуляции специалиста.

Ключевые слова: толерантность, профессиональная толерантность, мотивационно-смысловые факторы, толерантный, компетентность, педагог.

Вступ. Динаміка суспільних змін і соціальних процесів, які відбуваються в різних сферах життєдіяльності особистості, зокрема в професійній, вимагає вдосконалення професійної культури різноманітних типів та рівнів, що потребує постійного моделювання й проєктування системи професійної адаптації фахівця, у якій найчастіше першочергове місце відведено професійній толерантності особистості. Установка на толерантність як на активну життєву позицію та вміння регулювати власну поведінку відповідно до норм професійної діяльності й вимог міжособистісної взаємодії особливо актуальна для фахівців педагогічної діяльності. Також досягнення толерантної рівноваги в педагогічному середовищі співвідносне з аналізом мотиваційносмислових чинників поведінки професіонала, оскільки цей аспект розгляду проблеми дає змогу актуалізувати питання вивчення фахівця як суб’єкта професійної діяльності, який відповідальний за формуван- 
ня власного внутрішнього потенціалу та ставлення до інших людей. Фактично в цьому контексті хотілося б підтримати науковий діалог читача.

Mema дослідження - теоретичне обгрунтування та емпірична верифікація толерантності педагога засобом операціоналізації мотиваційно-смислових індикаторів толерантної компетентності й механізмів iї функціонування залежно від стажу його професійної діяльності.

Для цього потрібно виконати такі завдання: окреслити концептуальні позиції вивчення мотиваційно-смислової детермінації професійної толерантності педагога; на емпірико-діагностичному рівні визначити специфіку мотиваційно-смислової детермінації прояву толерантної компетентності педагогів залежно від стажу їхньої професійної діяльності.

Методи та процедура дослідження. Для досягнення мети й виконання поставлених завдань використано такі методи: теоретичні (аналіз, синтез, порівняння, абстрагування, узагальнення, систематизація наукової літератури щодо вивчення мотиваційно-смислової детермінації професійної толерантності педагогічних працівників); емпіричні (бесіда, спостереження, тестування із застосуванням методик діагностики професійної педагогічної толерантності (Ю. Макаров), діагностики мотиваційної структури особистості (В. Мільман), діагностики соціально-психологічних установок особистості в мотиваційнопотребнісній сфері (О. Потьомкіна), визначення смисложиттєвих орієнтацій (Д. Леонтьєв), методики вивчення ціннісних орієнтацій (Д. Леонтьєв), опитувальника комунікативної толерантності (В. Бойко), тесту-опитувальника на ригідність; шкали толерантності до невизначеності Д. Маклейна (адаптація Е. Луковицької), методів математичної статистики (дискримінантний аналіз, критерій КраскелаУоллеса, факторний аналіз, множинний регресійний аналіз). Статистичну обробку даних здійснено за допомогою комп'ютерного забезпечення SPSS для Windows (версія 13.0).

Вибірку дослідження становили педагогічні працівники Волинського коледжу національного університету харчових технологій, Технічного коледжу Луцького національного технічного університету та Луцького педагогічного коледжу віком від 25 до 63 років (n=201), диференційовані за стажем роботи (стаж роботи до 5-ти років (професійна адаптація) (n=54); від 5-ти до 10-ти років (професійна реалізація) $(\mathrm{n}=66)$, стаж роботи понад 10 років (професійна стагнація) $(n=81))$. 
Обговорення результатів. Унаслідок теоретичного огляду проблеми в психологічній літературі вдалось окреслити основні категоріально-понятійні контури феномену професійної толерантності особистості як реалізованої готовності до усвідомлених особистісних дій професіонала, спрямованих на досягнення гуманістичних відносин між фахівцем і людьми. Найчастіше на професійній толерантності наголошують тоді, коли згадується ії комунікативний аспект (Есипов, 2017). Так, професійна толерантність фахівців соціальної сфери розглядається як стійкість до дії професійного стресу, збереження соціально-психологічної адаптивності фахівця, здатність вирішувати конфліктні ситуації в професійній сфері через розуміння й сприйняття різних поглядів, відмову від професійного догматизму, спроможність саморозвитку та участі в розвитку професійної культури. Ця інтерпретація дає змогу розглядати професійну толерантність і як інтегральну якість особистості, і як світоглядну позицію, і як норму поведінки, що $є$ однією зі складових частин професійної етики (Черникова, 2016). У професійному становленні толерантний фахівець здатний чітко окреслити межі свого «Я», ухвалювати відмінності у відносинах, залишаючись при цьому досить стійким. Дійсна толерантність фахівця - це внутрішня інтегративна характеристика, яка поєднує систему установок особистості, професійних цінностей, психологічна стійкість (емоційна й моральна), сукупність індивідуальних, суб'єктних, особистісних, індивідуальних якостей (Лукаш, 2010). Тому є всі підстави для твердження, що професійна толерантність $є$ системотворчим чинником і гуманістично-ціннісною позицією стосовно людей, адже іiі основне призначення полягає в гуманному ставленні до природного середовища й суб'єктного довкілля, використанні грунтовних знань у сфері професійної діяльності та ділової комунікації та взаємодії, відтворенні соціальних норм і цінностей як основи виконання службових і громадянських обов'язків, а також у спроможності конструктивно діяти в складних i нестандартних умовах, не виходячи за рамки професійно прийнятної поведінки (Гайдук, 2017).

Сумуючи базові теоретичні позиції вивчення поставленої проблеми, ми розробили теоретичну модель структурної організації професійної толерантності педагога, яка містить такі компоненти: когнітивно-інформативний (визначається вміннями виконання професійних завдань через систему засвоєних кваліфікаційних знань i 
навичок, умінь та здібностей, які регулюють побудову нових перспектив професійного зростання), емоційно-регуляційний (уміщує емоційні характеристики фахівця, котрі визначають зміст переживання педагогічної діяльності, розуміння власних емоційних станів та емоцій інших людей), особистісно-комунікативний (визначається сформованою соціальною позицією й соціальними якостями фахівця, які зумовлюють його ефективне професійне самовизначення) і поведінковонормативний (характеризує рівень нормативної регуляції соціальної взаємодії особистості фахівця, що відображено в його поведінкових диспозиціях) (Гайдук, 2018). При цьому наголошено, що виокремлені компоненти професійної толерантності педагога тісно взаємопов'язані між собою та становлять комплекс когнітивних, емоційних, особистісних i поведінкових характеристик фахівця, які уреальнені в мотиваційно-смислових модусах їх продуктивного функціонування: операційно-смисловий модус; рефлексивно-смисловий модус, мотиваціийно-регуляційний (внутрішній) модус, мотиваційно-контролюючий (зовнішній) модус.

Зрозуміло, що в ході професіоналізації вчителя закономірними $є$ зміни в прояві професійної толерантності, які зумовлені віковими й фаховими особливостями професійної реалізації, що можуть призводити до загальнопрофесійних деформацій, які порушують цілісність фахівця та знижують професійно-ефективне функціонування (Virna, 2015). Але масштаб мотиваційно-смислової детермінації професійної толерантності фахівця, що задається його життєвим шляхом, є найоптимальнішим для опису педагогічної майстерності.

Із метою емпіричної експлікації виокремлених структурних компонентів професійної толерантності розроблено й проведено емпірико-діагностичне дослідження на вибірці педагогів, диференційованих за стажем роботи. Отримані результати продемонстрували виявлення реальної психологічної картини мотиваційно-смислової детермінації проявів професійної толерантності педагогів на кожному 3 етапів їх професіоналізації. На нашу думку, те, що забезпечує чіткість та організованість функціонального прояву професійної толерантності, може бути описано в конструкті толерантної компетентності педагога. Толерантність як одна з найважливіших інформативних рис педагога $\epsilon$ досить складним утворенням, у якому відображаються особливості освітньої культури й виховання особистості, досвід спілкування, цінності, потреби, інтереси, установки, 
характер, особливості мислення та стереотипи поведінки. Толерантні ознаки визначають життєвий шлях фахівця, його статус у найближчому оточенні й на роботі, просування в кар'єрі та виконанні професійних обов'язків засобом сформованих якостей, серед яких особливо виокремлюються естетичні, характерологічні й інтелектуальні (Mutz, 2001).

Виходячи з узагальненого розуміння професійної компетентності як невід’ємної складової частини культури професійної діяльності через володіння системою знань, умінь і навичок, достатньою для успішного виконання тих трудових завдань, які відповідають повсякденним та очікуваним на найближче майбутнє функціональним обов'язкам фахівця (Гура, 2006), спробуємо визначити толерантну компетентність як сукупність морально-практичних знань і досвіду та морально-аналітичних умінь і навичок, котрі дають змогу діяти самостійно й відповідально в ситуаціях морального вибору та допомоги іншим людям, виявляти й аргументувати позицію позитивної взаємодії з іншими людьми.

Отримані в ході емпіричного дослідження результати продемонстрували виявлення реальної психологічної картини мотиваційносмислової детермінації професійної толерантності педагога на кожному з етапів професіоналізації.

Послідовність використання методів математичної статистики й, зокрема проведення факторного аналізу (у групі 1 факторну модель становлять «загальножиттєва реальна мотивація» (27\% дисперсії), «соціальна гнучкість» $(13,9$ \%), «змішана астенічність» $(11,0 \%)$, «життєва неосмисленість» $(10,6 \%)$, «стенічні емоційні переживання» (7,34 \%), «комунікативна інтолерантність» $(7,11 \%)$; у групі 2 - «соціальний статус» $(25,1 \%)$, «комфорт» $(13,8 \%)$, «альтруїстична орієнтація» (10,3\%), «ригідність» $(9,69 \%)$, «стенічні емоційні переживання» $(9,06 \%)$, «орієнтація на свободу» (6,86 \% дисперсіi); у групі 3 виокремлено такі фактори, як «активне спілкування» $(16,3 \%)$, «підтримка життєзабезпечення» $(14,5 \%)$, «творча активність» $(13,2 \%)$, «соціальний статус» $(10,5 \%)$, «професійна автономність» $(8,53 \%)$, «осмисленість життя» $(7,45 \%$ дисперсії)) та регресійного аналізу (серед прогностичних детермінант професійної толерантності в групі педагогів зі стажем професійної діяльності до 5-ти років виокремлено фактори «соціальна гнучкість» $(\beta=0,509)$, «загальножиттєва реальна мотивація» $(\beta=0,444)$, «стенічні емоційні переживання» 
$(\beta=0,391)$; у групі педагогів зі стажем 5-10 років - фактори «орієнтація на свободу» $(\beta=0,512)$, «альтруїстична орієнтація» $(\beta=0,390)$, «комфорт» $(\beta=0,225) ;$ у групі працівників із педагогічним стажем понад 10 років - фактори «соціальний статус» $(\beta=0,684)$, «підтримка життєзабезпечення» $(\beta=0,302)$, «осмисленість життя» $(\beta=0,266))$, що дало змогу зафіксувати психологічний факт трансформації змісту професійної толерантності від емоційної насиченості їх для педагогів зі стажем професійної діяльності до 5-ти років до комунікативної оперативності для педагогів зі стажем 5-10 років і результативної регламентованості для педагогів зі стажем роботи понад 10 років.

Також на цьому етапі враховано дані методики вивчення ціннісних орієнтацій Д. Леонтьєва, що сприяло додатковому аналізу змісту термінальних (тих позитивних рис, які проявляються в поведінці) та інструментальних (цілі, до яких прагне людина) цінностей випробуваних у кожній досліджуваній групі педагогів. Процедура фіксації вміщує не лише визначення модальності цінностей, але й відсотковий рівень їх прояву.

Емпірично експлікований зміст структурних компонентів професійної толерантності педагогів дає змогу обгрунтувати мотиваційносмислові індикатори визначення професійної толерантності в педагогів із різним стажем професійної діяльності: для педагогічних працівників зі стажем до 5-ти років властива «емоційно-раціональна» толерантність; зі стажем 5-10 років - «автономно-безкорислива» толерантність; зі стажем професійної діяльності понад 10 років «статусно-нормативна» толерантність. Структурно-функціональну організацію мотиваційно-смислових індикаторів професійної толерантності педагогів на кожному з етапів їх професійного становлення представлено на рис. 1.

Так, для педагогів зі стажем професійної діяльності до 5-ти років зазначена емоційно-раціональна толерантна компетентність, яка пояснює адаптивну збалансованість педагогів на психоресурсному рівні реагування та функціональної активації засобом залучення різноманітних регуляційних систем функціонування, що дає змогу фахівцю використовувати ресурси, котрі $\epsilon$ адекватними ситуації, а отже, проявляти гнучкість і мінливість емоційного реагування на фоні високої працездатності й активності. Ці педагоги відрізняються вираженою робочою спрямованістю, схильністю до неординарних та оригінальних рішень, емоційною стійкістю, врівноваженістю й допит- 
ливістю. Високі показники ефективності їх толерантної взаємодії підкріплені вираженими здібностями витриманості та досконалості у виконанні поставлених завдань. Смисложиттєві орієнтири на емоційну насиченість життя визначаються термінальними цінностями дисциплінованості, вихованості, старанності й працелюбності, а також інструментальними цінностями міжособистісних відносин. Цього педагога відрізняють такі індивідуальні особливості, як природна схильність до навчання, інтернальність як схильність пов'язувати свої успіхи та невдачі з власними якостями й виявленими зусиллями, віра у власні ефективність і можливості та загострене відчуття задоволення від процесу навчання, а також для них дуже важливе переживання відсутності соціального запиту з боку суспільства на підвищення рівня професійної компетентності педагога.

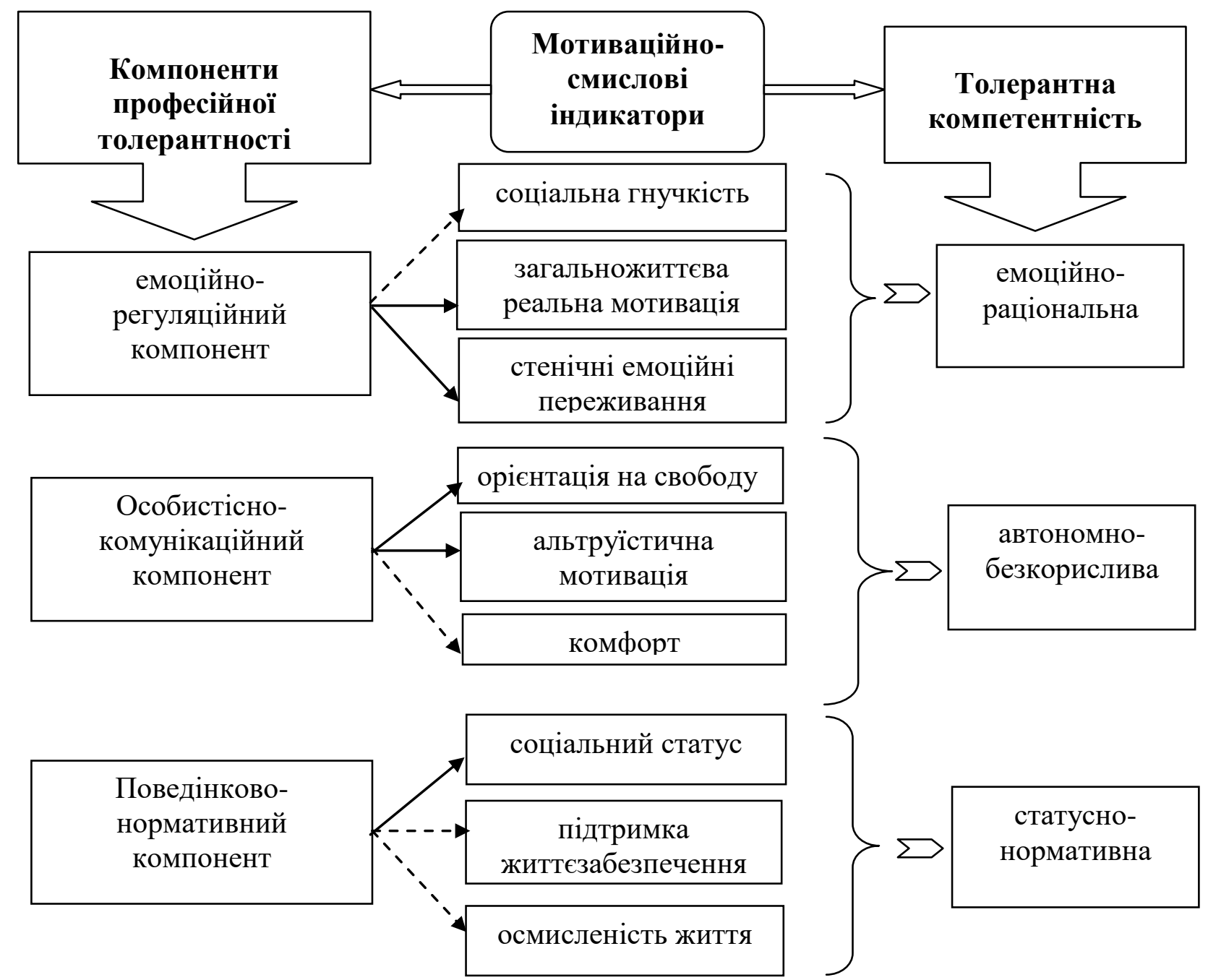

Рис. 1. Структурно-функиіональна організаиія мотиваційно-смислових індикаторів професійної толерантності педагогів 
Так, для педагогів зі стажем професійної діяльності 5-10 років властива автономно-безкорислива толерантна компетентність, яка відображає адекватний рівень професійної реалізації педагогічних працівників за рахунок розвинутих інтернальних здібностей міжособистісної взаємодії, цілеспрямованості, ініціативності й готовності допомагати іншим та чіткої усвідомленої позиції в досягненні мети й вираженого локусу контролю Я (високий рівень пізнання самої себе й іншої людини та відсутність корисливих інтересів і потреб щодо інших людей або груп). Альтруїстичні тенденції поведінки характеризують цих педагогів доброзичливими та дружелюбними, що можна розглядати як зразок у досягненні ними соціальної зрілості. Смисложиттєві орієнтири на досягнення мети в житті характеризуються безпосереднім емоційним світосприйняттям, а система інструментальних цінностей сповнена індивідуалізму життя. Педагог цієї форми толерантної компетентності відрізняється високим рівнем психологічного комфорту під час виконання професійних обов'язків, логічністю структурування навчального матеріалу, урахуванням власних інформаційних потреб та практичною спрямованістю педагогічної діяльності, розумінням інтеракційних законів психології сприйняття інформації дорослою людиною й умінням застосовувати особистісний підхід у навчальній діяльності; також для них важливим є визнання успіхів у їхній педагогічній діяльності з боку адміністрації навчального закладу, адже вони є зразком у визнанні себе самокерованою особистістю.

Так, для педагогів зі стажем професійної діяльності понад 10 років зазначена статусно-нормативна толерантна компетентність, яка характеризується психоресурсними ознаками професійної продуктивності за рахунок розвиненої моральної нормативності, регламентованості й витриманості, а також креативного посилення особистісноповедінкових якостей педагогів. Їх особистісний профіль визначається характеристиками неупередженості, позитивно-оптимістичної активності, доброзичливості, цілеспрямованості. Смисложиттєва орієнтація на результативність та осмисленість життя дає змогу цим педагогічним працівникам краще зорієнтовувати свою поведінку в бік конструктивної взаємодії з іншими з елементами чіткого усвідомлення неоднозначності й непередбачуваності життєвих подій, їхні життєвий досвід і багатогранність відображені в системі термінальних та інструментальних цінностей, де домінують цінності особистого життя. 
На фоні зазначених позитивних якостей цих фахівців відрізняють зниження темпу засвоєння нових знань, негативні емоційні переживання 3 приводу досвіду дії старої педагогічної парадигми зі всіма притаманними їй недоліками); для них також важливе визнання успіхів у їхній педагогічній діяльності з боку адміністрації навчального закладу через можливість отримання матеріальної винагороди, отримання нової посади, підвищення рівня авторитету серед колег за досягнуті результати в самоосвіті.

Вважаємо, що виокремлені структурні компоненти професійної толерантності особистості є внутрішньоопосередкованими комплексами особистісно-поведінкових властивостей, які дають змогу конкретизувати зміст толерантної компетентності педагогічних працівників, а також можуть бути розглянуті як психічні детермінанти діяльності, що $\epsilon$ не лише джерелом професійної активності й поведінки, але й факторами змін та реалізації особистості педагога. Також потрібно враховувати, що структурні компоненти професійної толерантності $€$ досить динамічними властивостями, які пов'язані 3 особливостями процесу особистісного становлення, котрий відображає зміну особистісно-поведінкових та інтерперсональних характеристик, а також опосередковані системою особистісно-професійних цінностей суб'єкта. Досліджуючи емоційну зрілість як умову професійної толерантності психологів, виокремлюємо такі психологічні особливості емоційної зрілості через експресивну, саморегулювальну й емпатійну форми iii прояву в структурі професійної толерантності засобом експлікації іiі ситуативно-домінуючих, комунікативно-відкритих та морально-емпатійних ознак залежно від стажу професійної діяльності психологів (Вірна, 2015).

У результаті порівняння регресійних моделей мотиваційносмислових особливостей прояву професійної толерантності педагогів iз різним стажем професійної діяльності помічено, що на кожному етапі професійного становлення педагогів провідну позицію займає один із компонентів професійної толерантності, а відтак є підстави для виокремлення психологічних ознак толерантної компетентності, сповнених морально-практичних знань і досвіду та морально-аналітичних умінь і навичок, які дають змогу діяти самостійно й відповідально в ситуаціях морального вибору та допомоги іншим людям, а також виявляти й аргументувати позицію позитивної взаємодії 3 іншими людьми на емоційному, комунікативному та поведінковому рівнях у 
різноманітних варіаціях прояву. Тому пропонуємо схематичний варіант динамічної організації прояву толерантної компетентності педагогічних працівників залежно від стажу їхньої професійної діяльності (рис. 2).

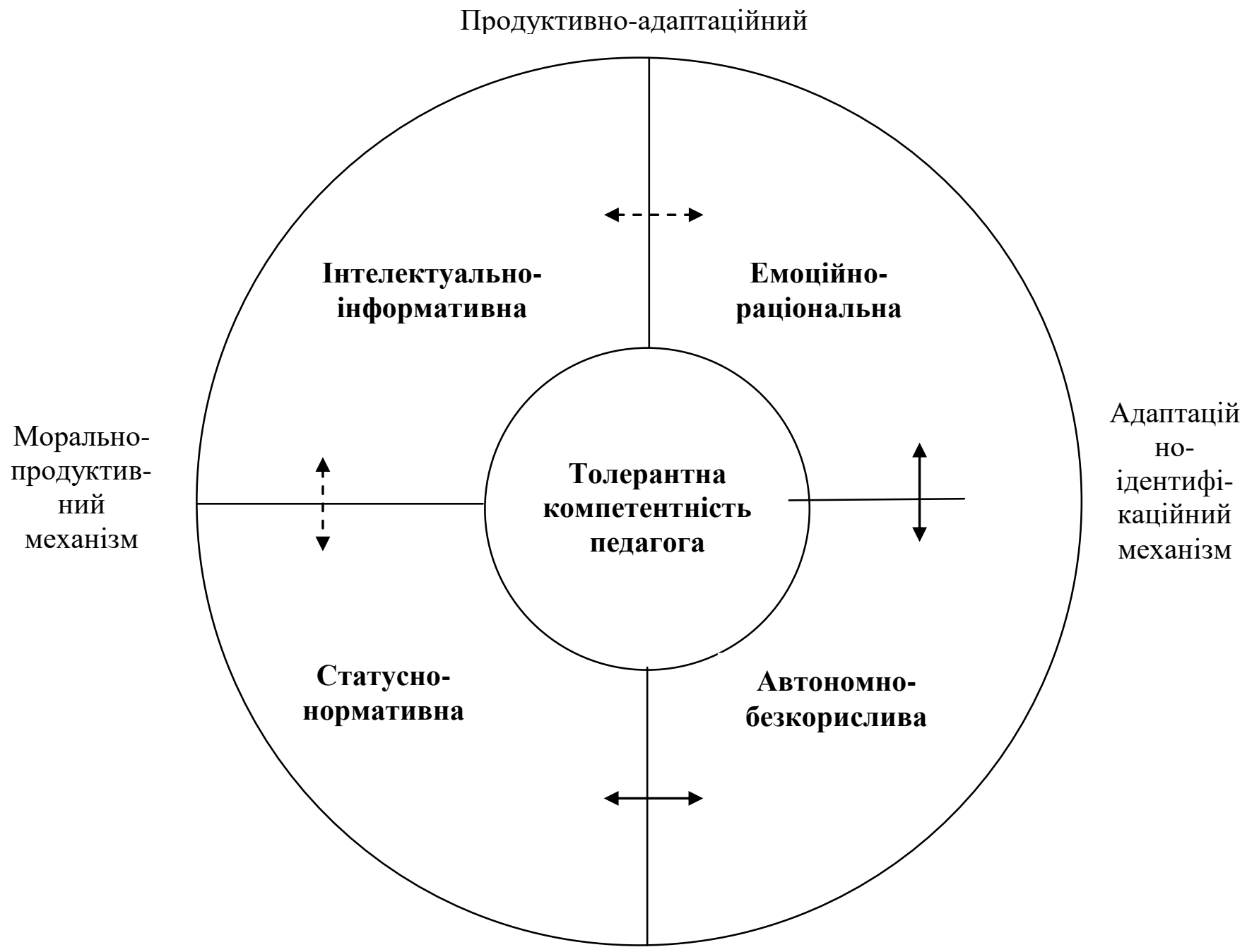

Ідентифікаційно-моральний

Рис. 2. Організація прояву толерантної компетентності педагогічних праиівників залежно від стажу їхньої професійної діяльності

Емпірично доведені форми толерантної компетентності (емоційно-раціональна, автономно-безкорислива, статусно-нормативна) відповідають теоретично експлікованим компонентам професійної толератності (емоційно-регуляційний, особистісно-комунікативний, поведінково-нормативний) у мотиваційно-смислових ознаках самореалізації педагога. Логічним є зазначення механізмів взаємозв'язку форм толерантної компетентності педагога, які є реальними засобами 
мотиваційно-смислової організації професійної діяльності педагога та його функціонального потенціалу.

Взаємозв'язок між емоційно-раціональною й автономно-безкорисливою формами толерантної компетентності проявляється засобом дії адаптаційно-ідентифікаційного механізму, що визначається рефлексивним усвідомленням вимог професійної діяльності засобом вироблення адекватної особистісної позиції толерантної взаємодії фахівця (рефлексивно-смисловий модус продуктивного прояву професійної толерантності); завдяки його дії відбувається безперервний процес зміни операцій, вчинків, мотивів, намірів тощо, які забезпечують професійну діяльність та актуальний рівень розвитку особистості, що, зі свого боку, впливає на набуття професійної ідентичності як результативної характеристики професійного досвіду, що є формою мотиваційного контролю й регуляції конкретних дій та психічних станів, котрі пов'язані з індивідуальними психологічними відмінностями (Vaillant, 2000). У результаті цих процесів у значущій для індивіда системі відносин виникає здатність уявляти себе, оцінювати й ставити на місце іншого, тобто емпатійність у переживаннях, рефлексивність, стійкість «Я», межі «Я», спрямованість та інтерес до іншого. Вираження толерантності як інтегративної характеристики, що характеризується стійкістю й здатністю до співпереживання, властиве особистості 3 розвиненою професійною свідомістю (Санникова, 2017).

Взаємозв'язок між автономно-безкорисливою та статусно-нормативною формами толерантної компетентності проявляється засобом дії ідентифікаційно-морального механізму, який окреслює нормативність i професійну регламентованість педагога в ознаках максимальної реалізації професійних й особистісних ідеалів життя; завдяки його дії відбувається формування морально-нормативних властивостей особистості, що $є$ основними атрибутами іiі усвідомленої можливості ціннісного та відповідального ставлення до професійної ролі, здібностей і нахилів, усвідомлення сутності розуміння професійних вимог, що ставляться до особистості під час професійної діяльності. Цей механізм визначається сформованими особистісними диспозиціями, у яких зафіксовано загальну спрямованість інтересів особистості стосовно сфери соціально-професійної активності (Галян, 2014). У професійному становленні толерантний фахівець здатний чітко окреслити межі свого «Я», оцінювати відмінності у відносинах, залишаючись при 
цьому досить стійким, а ідентифікаційно-моральний механізм поєднує систему установок особистості, систему професійних цінностей, психологічну стійкість (емоційну й моральну), сукупність індивідуальних, суб'єктних, особистісних, індивідуальних якостей, де особливе місце відведено самооцінці особистістю власних особливостей і можливостей, які забезпечують гнучкість у досягненні цілей, ставлення до успіху та невдач, схвалення чи несхвалення.

Унаслідок того, що в ході дослідження незадіяним виявився когнітивно-інформативний компонент професійної толерантності, спробуємо визначити його психологічний статус в організаційній схемі прояву толерантної компетентності педагога у формі інтелектуальнопродуктивної толерантної компетентності, що відповідає когнітивно-інформативному складнику професійної толерантності, що проявляється в межах інформаційно-нормативної відповідності людини й професійного середовища. Ми не виключаємо задіяності форми інтелектуально-продуктивної толерантної компетентності в ході професійної реалізації педагога. Адже когнітивно-інформаційний аспект в професійній діяльності завжди досліджується 3 погляду здійснення контрольно-оцінювальної функції та пов'язується із завершальним етапом виконання професійного завдання будь-якої складності, а отже, саме інформаційно-когнітивний аспект відповідальний за рефлексивне підбиття підсумків професійної діяльності (McLaughlin, 2007).

Тому $є$ всі підстави вважати, що саме форма інтелектуальнопродуктивної толерантної компетентності задіяна у функціонуванні емоційно-раціональної та статусно-нормативної толерантної компетентності засобом: 1 - морально-продуктивного механізму як взаємозв'язок між статусно-нормативною й інтелектуально-продуктивною формами толерантної компетентності у вигляді різноманітних варіантів модифікації регламентованої професійної діяльності, що може трактуватися як інноваційний і творчий підхід до виконання професійних завдань; дія цього механізму позбавляє особистість орієнтації на конкретні соціальні еталони, вчить іiі шукати або самостійно формувати власні життєві взірці; 2 - продуктивно-адаптаціийного механізму як взаємозв' язок між інтелектуально-продуктивною та емоційно-раціональною формами толерантної компетентності педагога, яка фактично визначає його професійне покликання як єдність суб' єктивних нахилів і здібностей до професійної діяльності, що підтримує й примножує індивідуальну цілеспрямованість життя 
людини; дія цього механізму відповідає за інтуїтивну оцінку інформації й трансформацію поведінки в здобуванні нового знання.

Отже, добре простежуємо роль «подвійного стану» інтелектуально-продуктивної форми толерантної компетентності педагога, зокрема обрання потрібної рефлексивної позиції щодо професійної реалізації. Особистість завжди знає та реально відчуває, що вона обрала правильний шлях життєдіяльності, що іiі роль і місце в житті суспільства відповідають реальній можливості найбільш повного вдосконалення й прояву своїх здібностей, реальній можливості бути найбільш корисною для суспільства та бути ним визнаною (Ставицький, 2017). Але вихід у рефлексивну позицію сам по собі $€$ значним інтелектуальним зусиллям. Крім того, він може ускладнюватись у зв'язку з наявністю глибоких емоційних переживань із приводу професійної ситуації або неусвідомлюваним страхом перед тим, що потрібно буде самому собі зізнатись у власних помилках тощо.

Толерантна компетентність педагога багато в чому залежать від психологічних особливостей його особистості, які визначають можливість адекватної професійної поведінки в різноманітних умовах соціально-професійного життя. Тому зосередження уваги на виокремлених механізмах функціонування толерантної компетентності педагога дасть змогу визначити адекватний вплив мотиваційносмислової детермінації на систему професійної саморегуляції фахівця (Vohs, 2004).

Проведене дослідження демонструє, що внутрішня структура толерантної компетентності педагога вміщує комплекс мотиваційносмислових утворень, які відповідають за розуміння особистих потреб на підставі самоаналізу, самопізнання, самообліку сильних і слабких сторін своєї діяльності, критичного ставлення до будь-якої отриманої інформації й вироблення особистісної позиції в процесі здобуття певних знань щодо толерантної взаємодії, гнучкості використання нових технологій інформації та комунікації; адекватного оцінювання значення здобутих знань у своїй діяльності, уміння співпрацювати 3 людьми різних вікових категорій, проявляти толерантне ставлення до опозиційної думки тощо. При цьому очевидно те, що в ході розвитку толерантної компетентності поступово утворюються якісно нові особистісні утворення, формуються нові психологічні структури на основі узагальнення й перетворення структур попереднього змісту 
досвіду. А це означає, що безперервне накопичення толерантних умінь i навичок, нових способів орієнтації у сфері професійних вимог приводить до появи нових можливостей людини.

Висновки та перспективи. Логіка наукових фактів, отриманих у проведеному дослідженні, доводить, що толерантна компетентність як когнітивно-афективна здатність особистості фахівця є складною динамічною системою, суть якої полягає в умінні давати опосередковану емоційну та поведінкову відповідь на переживання іншого в поєднанні 3 рефлексією його внутрішніх станів, думок і почуттів. Саме тому в сучасній системі професійної реалізації педагогічних фахівців потрібно враховувати особистісні резерви психоемоційної сфери особистості, конструктивне використання яких дасть змогу ефективно організувати практичну діяльність цих фахівців, у якій би повністю був реалізований простір для вироблення нових способів толерантної взаємодії й професійного мислення, для самовідданого занурення в професію на основі оволодіння техніками рефлексій, розуміння та комунікації.

Перспективами вважаємо вдосконалення критеріїв й обгрунтування процедури дослідження когнітивно-інформаційних ознак мотиваційно-смислової детермінації професійної толерантності педагога, а також створення прикладних програм удосконалення змісту його толерантної компетентності.

\section{Література}

1. Вірна, Ж. П., Кандиба, М. О. (2015). Емоційна зрілість психолога: тенденції і закономірності прояву в структурі професійної толерантності. Теоретичні і прикладні проблеми психології, 3(38), 104-119.

2. Гайдук, Г. А. (2018). Модель структурної організації професійної толерантності педагога. Психологічні перспективи, 32, 73-84. DOI: https://doi.org/ 10.29038/2227-1376-2018-32-73-84

3. Галян, I. М. (2014). Методи, умови та шляхи становлення професійної саморегуляції у майбутніх педагогів. Особистісно-професійний розвиток майбутнього педагога: монографія. Дрогобич: Вид. відд. Дрогобиц. держ. пед. ун-ту ім. Івана Франка, 209-213.

4. Гура, О. І. (2006). Психолого-педагогічна компетентність викладача вищого навчального закладу: теоретико-методологічний аспект. Запоріжжя: Гуманіт. ун-т «Запорізький інститут державного та муніципального управління».

5. Есипов, М. А. (2017). Содержание и структура феномена коммуникативной толерантности в отечественных психолого-педагогических исследованиях. Мир науки, 5 (6). URL: https://mir-nauki.com/PDF/22PDMN617.pdf 
6. Лукаш, Л. А. (2010). Структурно-динамический подход в исследовании закономерностей профессионального становлення. Соџиология и сочиальная политика, 10, 36-48.

7. Санникова, О. П., Кузнецова, О. В. (2017). Системный анализ адаптивности личности. Одесса: Изд-во ВМВ.

8. Ставицький, О. О., Прокопчук, О. В. (2015). Мотивація успіху та іміджева компетенція майбутніх психологів. Украӥнський психолого-педагогічний науковий вісник, 4(04), 110-113.

9. Черникова, И. В., Луговая, О. В. (2016). Профессиональная толерантность специалистов социальной сферы: комплексная характеристика и технологии формирования. Вопросы современной педагогики и психологии: свежий взгляд и новые решения: сб. науч. трудов по итогам междунар. науч.-практ. конф. Ставрополь: Изд-во «Инновационный центр развития образования и науки», 124-128.

10. Haiduk, H. (2017). Wplyw checi osiagniecia sukcesu na formacje tolerancyjnego zachowania zawodowego nauczyciela. Area nauki, 1(1), 29-37.

11. McLaughlin, K. A., Borkovec, T. D., Sibrava, N. J. (2007). The effects of worry and rumination on affect states and cognitive activity. Behavior Therapy, 38, 23-38.

12. Mutz, D. C. (2001). Tolerance. International encyclopedia of social and behavioral sciences, 23, 15766-15771.

13. Vaillant, G. (2000). Adaptive mental mechanisms: Their role in a positive psychology. American Psychologist, 55 (1), 89-98.

14. Virna, Zh. (2015). Professional Deformations: Tendencies, Dynamics and Risks of Manifestation. Annales Universitatis Mariae Curie-Skłodowska, 2(28), 123136.

15. Vohs, K. D., Vohs, K. D., Baumeister, R. F. (2004). Understanding SelfRegulation: An Introduction. Handbook of self-regulation: research, theory, and applications. Eds. R. F. Baumeister, K. D. Vohs. New-York: Gulford Press, 1-12.

\section{References}

1. Virna, Zh. P., Kandyba, M. O. (2015). Emotsiina zrilist psykholoha: tendentsii i zakonomirnosti proiavu $\mathrm{v}$ strukturi profesiinoi tolerantnosti [Emotional maturity psychology: tendencies and regularities in the structure of the professional tolerance]. Teoretychni i prykladni problemy psykholohii - Theoretical and applied problems of psychology, 3(38), 104-119 (in Ukrainian).

2. Haiduk, H. A. (2018). Model strukturnoi orhanizatsii profesiinoi tolerantnosti pedahoha [Model of Structural Organization of Professional Teacher's Tolerance.]. Psykholohichni perspektyvy - Psychological Prospects Journal, 32, 73-84. DOI: https://doi.org/10.29038/2227-1376-2018-32-73-84 (in Ukrainian).

3. Halian, I. M. (2014). Metody, umovy ta shliakhy stanovlennia profesiinoi samorehuliatsii u maibutnikh pedahohiv [Methods, conditions and ways of formation of professional self-regulation at future teachers]. Osobystisno-profesiinyi rozvytok 
maibutnoho pedahoha - Personal and professional development of the future teacher, 209-213. Drohobych: Vydavnychyi viddil Drohobytskoho derzhavnoho pedahohichnoho universytetu imeni Ivana Franka (in Ukrainian).

4. Hura, O. I. (2006). Psykholoho-pedahohichna kompetentnist vykladacha vyshchoho navchalnoho zakladu: teoretyko-metodolohichnyi aspect [Psychological and pedagogical competence of a teacher of higher education: theoretical and methodological aspect]. Zaporizhzhia: Humanitarnyi un-t «Zaporizkyi in-t derzh. ta munitsypalnoho upravlinnia» (in Ukrainian).

5. Esipov, M. A. (2017). Soderzhanie i struktura fenomena kommunikativnoy tolerantnosti $\mathrm{v}$ otechestvennyih psihologo-pedagogicheskih issledovaniyah [The content and structure of the phenomenon of communicative tolerance in domestic psychological and pedagogical research]. Mir nauki - World of Science, 5 (6). URL: https://mir-nauki.com/PDF/22PDMN617.pdf (in Russian).

6. Lukash, L. A. (2010). Strukturno-dinamicheskiy podhod $\mathrm{v}$ issledovanii zakonomernostey professionalnogo stanovlennya [Structural-dynamic approach in the study of the patterns of professional development]. Sotsiologiya $i$ sotsialnaya politika Sociology and Social Policy, 10, 36-48 (in Russian).

7. Sannikova, O. P., Kuznetsova, O. V. (2017). Sistemnyiy analiz adaptivnosti lichnosti [System analysis of personality adaptability]. Odessa: Izdatelstvo VMV (in Russian).

8. Stavytskyi, O. O., Prokopchuk, O. V. (2015). Motyvatsiia uspikhu ta imidzheva kompetentsiia maibutnikh psykholohiv [The motivation for the success and the ideological competence of the future psychologists]. Ukrainskyi psykholohopedahohichnyi naukovyi visnyk - Ukrainian Psychological and Pedagogical Science Bulletin, 4(04), 110-113 (in Ukrainian).

9. Chernikova, I. V., Lugovaya, O. V. (2016). Professionalnaya tolerantnost spetsialistov sotsialnoy sferyi: kompleksnaya harakteristika i tehnologii formirovaniya [Professional Tolerance of Social Sphere Specialists: Complex Characteristics and Formation Technologies]. Voprosyi sovremennoy pedagogiki $i$ psihologii: svezhiy vzglyad $i$ novyie resheniya: $s b$. nauch. trudov po itogam mezhdunar. nauch.-prakt. konf. - Questions of modern pedagogy and psychology: a fresh look and new solutions: collection of articles. scientific. works on the results of the international. scientific-practical conf., 124-128. Stavropol: Izdatelstvo «Innovatsionnyiy tsentr razvitiya obrazovaniya i nauki» (in Russian).

10. Haiduk, H. (2017). Wplyw checi osiagniecia sukcesu na formacje tolerancyjnego zachowania zawodowego nauczyciela. Area nauki, 1(1), 29-37.

11. McLaughlin, K. A., Borkovec, T. D., Sibrava, N. J. (2007). The effects of worry and rumination on affect states and cognitive activity. Behavior Therapy, 38, 23-38.

12. Mutz, D. C. (2001). Tolerance. International encyclopedia of social and behavioral sciences, 23, 15766-15771.

13. Vaillant, G. (2000). Adaptive mental mechanisms: Their role in a positive psychology. American Psychologist, 55 (1), 89-98. 
14. Virna, Zh. (2015). Professional Deformations: Tendencies, Dynamics and Risks of Manifestation. Annales Universitatis Mariae Curie-Skłodowska, 2(28), 123 136.

15. Vohs, K. D., Vohs, K. D., Baumeister, R. F. (2004). Understanding SelfRegulation: An Introduction. Handbook of self-regulation: research, theory, and applications. Eds. R. F. Baumeister, K. D. Vohs. New-York: Gulford Press, 1-12.

Received: 10.09 .2020 Accepted: 30.09.2020 